\title{
Mineral composition of pollen using inductively coupled plasma atomic emission spectroscopy
}

L Paulo, P Antunes, O Anjos

Planta Med 2014; 80 - P2P16

10.1055/s-0034-1394851

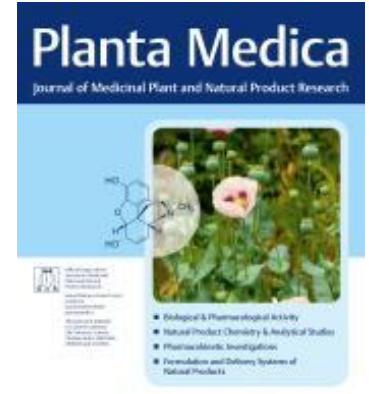

DOI:

https://www.thieme-connect.de/products/ejournals/abstract/10.1055/s-0034-1394851

\section{Congress Abstract}

Pollen collected by honey bees (bee pollen) is promoted as a health food supplement with a wide range of nutritional and health beneficial properties. While honey is an important source of proteins for the bee colony, pollen is the bees' main source for other important nutrients, such as minerals, fats, fibers, carbohydrates, and other substances. The composition of pollen is rather variable and depends on the botanical origin of the pollen. In this work we studied the mineral content of bee pollen of three botanical origins (Cistus ladanifer L., Rubus ulmifolius Schott, and Calluna vulgaris (L.) Hull) and two geographic sites in the central Portugal (Caniçal and Vale Grande). Inductively coupled plasma atomic emission spectrometry (ICP-AES) was used for the determination of cadmium, chromium, copper, iron, lead, manganese, and zinc. Prior to ICP-AES measurement, the samples were mineralized by treatment with $\mathrm{HNO}_{3}$ and $\mathrm{H}_{2} \mathrm{O}_{2}$ at $100{ }^{\circ} \mathrm{C}$ until complete digestion. The analyzed elements presented levels corresponding to the usual reference range [1]. The concentrations of micronutrients ( $\mathrm{Cu}, \mathrm{Fe}, \mathrm{Mn}$ and $\mathrm{Zn}$ ) presented characteristic profiles which differed between the three plant species, but where similar in the two geographic areas. The main minerals observed for $R$. ulmifolius and $C$. vulgaris were Fe and $\mathrm{Mn}$, and Zn for $C$. ladanifer. Heavy metals ( $\mathrm{Cd}, \mathrm{Cr}$ and $\mathrm{Pb}$ ) were present at low concentrations (Table 1), indicating that there were no sources of contamination. In conclusion, the determination of micronutrients in pollen could be suitable for the identification of botanical species. The investigation of element profile, in combination with modern statistical data evaluation techniques, can be a promising approach to identify the botanical source of pollen.

Keywords: micronutrients; pollen, ICP-AES

References:

[1] Campos MGR, Bogdanov S, Almeida-Muradian LB, Szczesna T, ManceboY, Frigerio C, Ferreira F. Pollen composition and standardisation of analytical methods. J Apic Res and Bee World 2008; 47: 156 - 163. 
Tab. 1: Mineral concentration of bee pollen $(\mathrm{mg} / \mathrm{kg})$.

\begin{tabular}{|c|c|c|c|c|c|c|c|c|}
\hline Sites & Species & $\begin{array}{l}\mathrm{Cu} \\
(\mathrm{mg} / \mathrm{kg})\end{array}$ & $\begin{array}{l}\mathrm{Fe} \\
(\mathrm{mg} / \mathrm{kg})\end{array}$ & $\begin{array}{l}M n \\
(m g / k g)\end{array}$ & $\begin{array}{l}\mathrm{Zn} \\
(\mathrm{mg} / \mathrm{kg})\end{array}$ & $\begin{array}{l}\text { Cd } \\
(\mathrm{mg} / \mathrm{kg})\end{array}$ & $\begin{array}{l}\mathrm{Cr} \\
(\mathrm{mg} / \mathrm{kg})\end{array}$ & $\begin{array}{l}\mathrm{Pb} \\
(\mathrm{mg} / \mathrm{kg})\end{array}$ \\
\hline \multirow[t]{3}{*}{ Caniçal } & $\begin{array}{l}\text { C. } \\
\text { ladanifer }\end{array}$ & 7.4 & 40.7 & 8.6 & 63.0 & $<0.1$ & 2.9 & $<1.4$ \\
\hline & $\begin{array}{l}R . \\
\text { ulmifolius }\end{array}$ & 12.7 & 80.5 & 203.0 & 47.0 & $<0.1$ & $<0.4$ & $<1.4$ \\
\hline & $\begin{array}{l}\text { C. } \\
\text { vulgaris }\end{array}$ & 8.8 & 123.4 & 266.0 & 36.0 & $<0.1$ & $<0.4$ & $<1.4$ \\
\hline \multirow[t]{3}{*}{$\begin{array}{l}\text { Vale } \\
\text { Grande }\end{array}$} & $\begin{array}{l}\text { C. } \\
\text { ladanifer }\end{array}$ & 7.4 & 39.8 & 9.0 & 46.0 & $<0.1$ & 2.8 & $<1.4$ \\
\hline & $\begin{array}{l}R . \\
\text { ulmifolius }\end{array}$ & 13.2 & 83.2 & 197.0 & 48.0 & $<0.1$ & $<0.4$ & $<1.4$ \\
\hline & $\begin{array}{l}\text { C. } \\
\text { vulgaris }\end{array}$ & 8.6 & 124.7 & 250.0 & 32.0 & $<0.1$ & 0.8 & $<1.4$ \\
\hline
\end{tabular}

